\title{
Screening tests for syphilis A comparison of the Treponema pallidum haemagglutination assay with two automated serological tests
}

\author{
D. E. MACFARLANE AND T. F. ELIAS-JONES \\ From The City Laboratory, Glasgow
}

SUMmARY Two Treponema pallidum haemagglutination assay (TPHA) tests (Wellcome and Fuzizoki) were compared with the automated reagin test and the automated Reiter protein complement-fixation test in a routine screening system. The Wellcome TPHA was shown to lack sensitivity, and it is recommended that it should be used at a lower screening dilution. The Fuzizoki TPHA recorded a significant number of false positive and false negative results, and was therefore inferior to the fluorescent treponemal antibody absorption (FTA-ABS) test as a definitive test for syphilis. It is suggested that the TPHA be used in conjunction with a reagin test to replace some of the more inadequate screening tests currently in use. The automated screening tests were shown to have a similar sensitivity to the TPHA as well as several other advantages; they are recommended for testing large numbers of specimens.

\section{Introduction}

The Treponema pallidum haemagglutination assay (TPHA), first described by Rathlev (1965) and later modified by Tomizawa and Kasamatsu (1966), has been used in many laboratories for the serological diagnosis of syphilis, but the function of this test and the interpretation of results have been subjects of much discussion. Garner et al. (1972) suggested that the TPHA had a similar sensitivity to the fluorescent treponemal antibody absorption (FTA-ABS) test and was therefore an acceptable alternative. Johnston (1972) stated that the sensitivity and specificity of the TPHA test compared favourably with the Treponema pallidum immobilisation (TPI) and the FTA-ABS tests. She recommended the TPHA as a simple alternative specific treponemal test that was suitable for laboratories not equipped to carry out the TPI or the FTA-ABS tests. Coffey et al. (1972) believed that a positive result to the reagin test, and a positive result to the TPHA test would indicate the presence of syphilis, and that the

Address for reprints: D. E. Macfarlane, The City Laboratory, 23 Montrose Street, Glasgow G1 1RN

Received for publication 29 June 1977
FTA-ABS test should be reserved for patients in whom the reagin test gave positive results and the TPHA negative sera. This opinion was not, however, shared by Blum et al. (1973), who recorded a significant number of false positive and false negative results with the TPHA; they considered it inferior to the FTA-ABS test as a specific test for syphilis. Much of the information about the TPHA has been obtained by comparing it with the TPI or the FTA-ABS tests on selected groups of sera. A few authors (O'Neill et al., 1973; Sequeira and Eldridge, 1973), have used the TPHA as a screening test and compared it with standard screening tests-such as, the cardiolipin Wassermann reaction (CWR), the Reiter protein complement-fixation test (RPCFT), and the Venereal Diseases Research Laboratory (VDRL) slide test. Recent work in this laboratory has shown that an automated screening procedure, consisting of the automated reagin test (ART) and the automated Reiter protein complement-fixation test (ARPCFT), was considerably more sensitive than the standard manual tests. It was therefore decided to compare the TPHA with the automated screening tests, using the two kits widely available at present-that is, the Wellcome TPHA and the Fuzizoki TPHA. 


\section{Materials and methods}

The Wellcome TPHA was performed with microtitre equipment in accordance with the manufacturer's instructions using the recommended dilution of $1: 80$, and also with a starting dilution of $1: 40$. The Fuzizoki TPHA was tested in accordance with the manufacturer's instructions, using the micromethod.

The method used for the automated tests described by Macfarlane et al. (1976) was slightly modified. The complement titration was performed using a weak positive serum and the end point was selected to give a predetermined reading with this serum. This allowed more precise control of the sensitivity and better reproducibility of the test.

Of the samples received for testing, $80 \%$ came from venereal disease clinics; the remaining $20 \%$ consisted of antenatal specimens and sera from hospitals and general practitioners that had been submitted for routine investigation or to comply with emigration requirements. All sera were tested in parallel using the automated tests and the TPHA. Sera which gave a positive result in any one of the tests were checked using the FTA-ABS test. The comparison was divided into three separate sections -namely, the Wellcome TPHA, the Wellcome TPHA 1:40, and the Fuzizoki TPHA.

\section{Results}

The results obtained with the Wellcome TPHA were disappointing. It detected only 23 positive results compared with 29 by the ARPCFT (Table 1 ).

Table 1 Comparison of Wellcome TPHA with automated tests on 1280 sera

\begin{tabular}{llllc}
\hline & $\begin{array}{l}\text { Total } \\
\text { positive }\end{array}$ & $\begin{array}{l}\text { True } \\
\text { positive }\end{array}$ & $\begin{array}{l}\text { False } \\
\text { positive }\end{array}$ & $\begin{array}{l}\text { False } \\
\text { negative }\end{array}$ \\
TPHA & 23 & 22 & 1 & 7 \\
ARPCFT & 29 & 26 & 3 & 3 \\
ART & 19 & 19 & 0 & 10 \\
ART and ARPCFT & 32 & 29 & 3 & 0 \\
ART and TPHA & 26 & 25 & 1 & 4 \\
\hline
\end{tabular}

The comparison was therefore repeated using a screening dilution of 1:40 instead of the recommended $1: 80$. This considerably improved the sensitivity as shown by the results (Table 2). The TPHA detected 32 positive results, compared with 28 by the ARPCFT and 23 by the ART. The increased sensitivity gave five fewer false negative results but there was a corresponding increase, from one to five, in the number of false positive results. The most sensitive combination of tests was the ART and TPHA which detected 33 true positives,
Table 2 Comparison of Wellcome TPHA (1:40) with automated tests on 1258 sera

\begin{tabular}{llllc}
\hline Test & $\begin{array}{l}\text { Total } \\
\text { positive }\end{array}$ & $\begin{array}{l}\text { True } \\
\text { positive }\end{array}$ & $\begin{array}{l}\text { False } \\
\text { positive }\end{array}$ & $\begin{array}{l}\text { False } \\
\text { negative }\end{array}$ \\
\hline TPHA & 37 & 32 & 5 & 2 \\
ARPCFT & 29 & 28 & 1 & 6 \\
ART & 23 & 23 & 0 & 11 \\
ART and ARPCFT & 32 & 31 & 1 & 3 \\
ART and TPHA & 38 & 33 & 5 & 1 \\
\hline
\end{tabular}

compared with 31 detected by the ART and ARPCFT.

The Fuzizoki TPHA recorded 33 true positives, 4 false positives, and 5 false negatives; the corresponding figures for the ARPCFT were 30,3 , and 8 and for the ART 27,0, and 11 (Table 3). The combination of ART and TPHA (36 positive results)

Table 3 Comparison of Fuzizoki TPHA and automated tests on 1371 sera

\begin{tabular}{llllc}
\hline Test & $\begin{array}{l}\text { Total } \\
\text { positive }\end{array}$ & $\begin{array}{l}\text { True } \\
\text { positive }\end{array}$ & $\begin{array}{l}\text { False } \\
\text { positive }\end{array}$ & $\begin{array}{l}\text { False } \\
\text { negative }\end{array}$ \\
\hline TPHA & 37 & 33 & 4 & 5 \\
ARPCFT & 33 & 30 & 3 & 8 \\
ART & 27 & 27 & 0 & 11 \\
ART and ARPCFT & 38 & 35 & 3 & 3 \\
ART and TPHA & 41 & 36 & 5 & 2 \\
\hline
\end{tabular}

was marginally more sensitive than the ART and ARPCFT ( 35 positive results), while the latter combination was more sensitive than the TPHA on its own (33 positive results).

The two TPHA tests missed seven cases of syphilis (Tables 4 and 5). Five of these were latent, one was congenital, and one primary.

Table 4 Conflicting results: Automated tests compared with TPHA (Fuzizoki)

\begin{tabular}{|c|c|c|c|c|c|}
\hline \multirow[b]{2}{*}{ Sample } & \multicolumn{4}{|c|}{ Test results } & \multirow[b]{2}{*}{ Clinical diagnosis } \\
\hline & $A R P C F T$ & $A R T$ & $F T A$ & $T P H A$ & \\
\hline 1 & + & - & ++ & - & Treated primary syphilis \\
\hline 2 & - & - & - & + & No history of syphilis \\
\hline 3 & - & - & - & $+++t$ & No history of syphilis \\
\hline 4 & - & - & - & + & No history of syphilis \\
\hline 5 & - & - & + & $+++t$ & Treated secondary syphilis \\
\hline 6 & - & $+\mathbf{N}$ & ++ & - & Old congenital syphilis \\
\hline 7 & + & - & - & - & No history of syphilis \\
\hline 8 & + & $+\mathbf{N}$ & + & - & Early latent syphilis \\
\hline 9 & - & - & - & + & No history of syphilis \\
\hline 10 & + & - & - & - & No history of syphilis \\
\hline 11 & + & - & - & - & No history of syphilis \\
\hline 12 & - & - & + & + & Treated secondary syphilis \\
\hline 13 & - & - & + & + & Treated primary syphilis \\
\hline 14 & + & & ++ & - & Late latent syphilis \\
\hline 15 & + & $+1 / 2$ & + & - & Late latent syphilis \\
\hline
\end{tabular}


Table 5 Conflicting results: Automated tests compared with TPHA (Wellcome 1:40)

\begin{tabular}{|c|c|c|c|c|c|}
\hline \multirow[b]{2}{*}{ Sample } & \multicolumn{4}{|c|}{ Test results } & \multirow[b]{2}{*}{ Clinical diagnosis } \\
\hline & $A R P C F T$ & $A R T$ & $F T A$ & TPHA & \\
\hline 16 & - & - & - & + & No history of syphilis \\
\hline 17 & - & - & ++ & + & Treated primary syphilis \\
\hline 18 & - & - & - & + & No history of syphilis \\
\hline 19 & - & - & 一 & + & No history of syphilis \\
\hline 20 & - & - & - & + & No history of syphilis \\
\hline 21 & + & - & - & - & No history of syphilis \\
\hline 22 & + & - & ++ & - & Late latent syphilis \\
\hline 23 & + & $+\mathbf{N}$ & $+t+$ & - & Treated latent syphilis \\
\hline 24 & - & - & + & ++ & Old treated case \\
\hline 25 & - & - & $+t$ & + & Treated early syphilis \\
\hline 26 & - & - & - & + & No history of syphilis \\
\hline
\end{tabular}

\section{Discussion}

The lack of sensitivity of the Wellcome TPHA was one of several surprising discoveries made in this comparison. Investigation of the methods described by the two manufacturers of the TPHA tests reveals a discrepancy which partly explains this. The Wellcome TPHA microtest uses $0.075 \mathrm{ml}$ of a 1:80 dilution of a patient's serum to which is added $0.025 \mathrm{ml}$ of test cell suspension, giving a true dilution of 1:107. The Wellcome TPHA test in effect tests at a a higher serum dilution than the Fuzizoki TPHA, which uses a true final dilution of $1: 80$. When the test was repeated with a true final dilution of $1: 40$, there was a marked improvement in sensitivity but a correspondingly slight loss of specificity. Testing at this dilution the Wellcome TPHA compared favourably with the automated tests, being slightly more sensitive than the ART and ARPCFT combination.

The Fuzizoki TPHA was slightly less sensitive than the automated tests, detecting 33 of the 35 true positives recorded by the ART and ARPCFT combination. In the comparisons summarised in Tables 2 and 3, the TPHA was slightly more sensitive than the ARPCFT, and the most sensitive combination of tests was the ART and TPHA, although the difference was marginal in the case of the Fuzizoki TPHA. Somewhat surprisingly, the most specific test in all three comparisons was the ART, with a total of 69 positives and no false negatives, thus confirming our earlier observations on this test (Macfarlane et al., 1976). The false positive rate for the Wellcome TPHA 1:40 was $13.5 \%$ (five out of 37), and for the Fuzizoki TPHA $10.8 \%$ (four out of 37), but the Wellcome TPHA 1:40 recorded a lower false negative rate of $0.16 \%$ compared with $0.32 \%$ for the Fuzizoki TPHA. These figures differ in many respects from those reported by other authors (Table 6). In view of the methods used by previous authors it is probable that the percentage of false

Table 6 Analysis of results given in other papers on the TPHA test

\begin{tabular}{|c|c|c|c|c|c|c|c|c|c|}
\hline \multirow[b]{2}{*}{ Authors } & \multirow[b]{2}{*}{ Date } & \multirow[b]{2}{*}{$\begin{array}{l}\text { Type of } \\
\text { sample }\end{array}$} & \multirow[b]{2}{*}{$\begin{array}{l}\text { Approx. } \\
\text { pos./neg. } \\
\text { ratio }\end{array}$} & \multirow[b]{2}{*}{$\begin{array}{l}\text { Tests } \\
\text { used in } \\
\text { compari- } \\
\text { son }\end{array}$} & \multicolumn{2}{|c|}{ Percentage of } & \multirow[b]{2}{*}{$\begin{array}{l}\text { Sensiti- } \\
\text { vity in } \\
\text { primary } \\
\text { syphilis } \\
(\%)\end{array}$} & \multirow[b]{2}{*}{$\begin{array}{l}\text { Overall } \\
\text { agreement } \\
(\%)\end{array}$} & \multirow[b]{2}{*}{ Conclusion } \\
\hline & & & & & $\begin{array}{l}\text { False } \\
\text { positive }\end{array}$ & $\begin{array}{l}\text { False } \\
\text { negative }\end{array}$ & & & \\
\hline Blum et al. & 1973 & $\begin{array}{l}\text { Selected } \\
\text { groups }\end{array}$ & $139: 167$ & $\begin{array}{l}\text { ART } \\
\text { FTA- } \\
\text { ABS }\end{array}$ & $8 \cdot 8$ & $6 \cdot 5-10 \cdot 3$ & - & $\begin{array}{l}\text { FTA/ } \\
\text { TPHA } \\
90 \cdot 2\end{array}$ & $\begin{array}{l}\text { Question reliability of TPHA. } \\
\text { Prefer FTA-ABS as definitive test }\end{array}$ \\
\hline Cox et al. & 1971 & $\begin{array}{l}\text { Selected } \\
\text { groups }\end{array}$ & $600: 400$ & $\begin{array}{l}\text { VDRL } \\
\text { FTA- } \\
\text { ABS }\end{array}$ & 3 & - & 75-94 & $\begin{array}{l}\text { FTA/ } \\
\text { TPHA } \\
96-99\end{array}$ & $\begin{array}{l}\text { Compares favourably with FTA- } \\
\text { ABS but less sensitive in primary } \\
\text { syphilis }\end{array}$ \\
\hline Johnston & 1972 & $\begin{array}{l}\text { Selected } \\
\text { groups }\end{array}$ & $866: 1643$ & $\begin{array}{l}\text { TPI } \\
\text { FTA- } \\
\text { ABS }\end{array}$ & $1 \cdot 2$ & $5 \cdot 2$ & 70 & $\begin{array}{l}\text { FTA/ } \\
\text { TPHA } \\
97 \cdot 8 \\
\text { TPI/ } \\
\text { TPHA } \\
96 \cdot 8\end{array}$ & $\begin{array}{l}\text { Compares favourably with FTA- } \\
\text { ABS and TPI: less sensitive in } \\
\text { primary syphilis }\end{array}$ \\
\hline O'Neill et al. & 1973 & $\begin{array}{l}\text { Routine } \\
\text { specimens }\end{array}$ & - & $\begin{array}{l}\text { CWR, } \\
\text { RPCFT, } \\
\text { VDRL, } \\
\text { FTA- } \\
\text { ABS }\end{array}$ & 0.025 & - & 一 & - & $\begin{array}{l}\text { Comparable with FTA-ABS: less } \\
\text { sensitive in primary syphilis }\end{array}$ \\
\hline Garner et al. & 1972 & $\begin{array}{l}\text { Selected } \\
\text { specimens }\end{array}$ & $355: 434$ & $\begin{array}{l}\text { FTA } \\
\text { TPI }\end{array}$ & - & - & - & $\begin{array}{l}\text { FTA/ } \\
\text { TPHA } \\
\text { 97 } \\
\text { TPI/ } \\
\text { TPHA } \\
96 \cdot 1\end{array}$ & $\begin{array}{l}\text { Equal in sensitivity and specificity } \\
\text { to FTA-ABS: less sensitive in } \\
\text { primary syphilis }\end{array}$ \\
\hline Le Clair & 1971 & $\begin{array}{l}\text { Selected } \\
\text { groups }\end{array}$ & $140: 200$ & $\begin{array}{l}\text { VDRL } \\
\text { TPI }\end{array}$ & 4 & 9 & 50 & - & $\begin{array}{l}\text { High level of sensitivity and } \\
\text { specificity: lacks sensitivity in } \\
\text { primary and congenital syphilis. }\end{array}$ \\
\hline Coffey et al. & 1972 & $\begin{array}{l}\text { Selected } \\
\text { groups }\end{array}$ & $365: 715$ & $\begin{array}{l}\text { VDRL } \\
\text { FTA }\end{array}$ & 一 & - & 65 & $\begin{array}{l}\text { FTA/ } \\
\text { TPHA } \\
92\end{array}$ & $\begin{array}{l}\text { Positive reagin and TPHA would } \\
\text { indicate syphilis: would reserve } \\
\text { FTA-ABS to check discrepancies }\end{array}$ \\
\hline
\end{tabular}


pusitive results recorded by the TPHA has been underestimated. Most comparisons were made on selected groups of sera with a positive:negative ratio ranging from $1: 2$ to $3: 2$ (Table 6); therefore only 40 to $60 \%$ of the specimens could have contained any false positive results, and these would then be taken as a percentage of a large number of true positive results. For example, Blum et al. (1973) detected 12 false positive TPHA results in 306 sera but, because of the large number of positives present, the false positive rate was $8.8 \%$. Similarly, Le Clair (1971) reported eight false positive results from 330 sera recording a false positive rate of $4 \%$. In this present comparison, nine false positive TPHA results were recorded from a total of 2629 sera, but as only 72 of these were from patients with syphilis the false positive rate was $12.5 \%$.

A similar situation exists in the recording of false negatives. If the TPHA is compared with a crude screening system, then few false negative results will be recorded. If selected groups are tested by the TPHA, the results will depend to a large extent on how these sera are chosen. If they contain a large number of sera from secondary, tertiary or old treated cases, few false negative results will be recorded, but if there are many sera from early cases, then the percentage of false negative results will greatly increase. Testing selected groups of sera is not therefore strictly comparable to routine laboratory work.

Several authors have previously noted that the TPHA is not a sensitive test for primary syphilis (Table 6). This could not be confirmed in the present series because, of the 72 positive results, only five were from patients with primary syphilis.

Gf the seven cases 'missed' by both TPHA tests (Tables 4 and 5), five were patients with latent syphilis. O'Neill et al. (1973) found reduced TPHA titres in latent syphilis and Johnston (1972) reported a reduction in sensitivity of the TPHA in latent syphilis. It is possible that the TPHA is not a very sensitive test for latent syphilis either.

As a quantitative test for syphilis, the TPHA suffers from the disadvantage that the levels of the antibody it detects vary greatly at the same stage of infection. As the antibody persists for many years even in cases of successfully treated syphilis it is, therefore, of little value for monitoring treatment.

Judged by all these criteria, the TPHA compares unfavourably with the FTA-ABS test, and we agree with Blum et al. (1973) that the latter should be the definitive test for treponemal infections.

For screening tests, specificity is of secondary importance. The main requirement is maximum sensitivity and as the Wellcome TPHA performed at a lower serum dilution than that recommended by the manufacturers was shown to be very sensitive, we suggest that this 'modified' TPHA, used in conjunction with a reagin test-such as the ART or the rapid plasma reagin test-would be an ideal combination. The dilution of $1: 40$ was arbitrarily chosen for this trial, and further investigation may reveal a more appropriate dilution. It seems clear that, performed as recommended by the maufacturers, the Wellcome TPHA is not a sufficiently sensitive screening test, and the fact that the Fuzizoki TPHA failed to detect five out of the 38 cases of syphilis suggests that it too should be performed at a lower screening dilution than $1: 80$.

This investigation demonstrated that the ARPCFT compares favourably with the TPHA in specificity and sensitivity. This is a point worth considering at a time when the standard manual RPCFT is being increasingly ignored in favour of the TPHA. Before this trend goes further, attempts should be made to improve the manual RPCFT by such modifications as the use of microtitre equipment, reduction of complement from 2 units to $1 \frac{1}{4}$ units, reduction of cell concentration from $2 \%$ to $1 \%$, and overnight fixation at $4^{\circ} \mathrm{C}$ to see how it would then compare with the TPHA.

In a straight comparison with the automated tests, the Wellcome TPHA 1:40 was shown to be slightly more sensitive (Table 2) and the Fuzizoki TPHA slightly less sensitive (Table 3 ). Although the most sensitive combination of tests in both comparisons was the ART and TPHA, the combination of ART and ARPCFT has many advantages. It is a fully automated screening system and capable of handling large numbers of specimens, compared with the partially mechanised TPHA. The results are available in the form of a permanent record in 40 minutes compared with a transient plate reaction which takes four hours. The comparative slight lack of sensitivity in the ARPCFT can be rectified by altering the colorimeter setting. The cost per specimen for the automated tests is $1.5 \mathrm{p}$ for a quantitative result compared with $6 \mathrm{p}$ for a qualitative TPHA result; and the ARPCFT certainly excels as a test to monitor treatment. The ARPCFT records levels as high as 10000 transmission lines (TL) in secondary syphilis, falling to zero in most successfully treated cases (Table 7). Thus both the ART and ARPCFT can be used as indicators of the stage of infection and the effect of treatment. We would therefore recommend the automated screening system for testing large numbers of specimens and suggest that the small-scale manual screening systems be replaced by a combination of TPHA and reagin test, recognising that the almost prohibitive cost of the TPHA may act as a deterrent to its use. 
Table 7 Treatment monitoring with automated tests

\begin{tabular}{|c|c|c|c|c|c|}
\hline Case no. & Date & $F T A$ & $A R P C F T$ & $A R T$ & Remarks \\
\hline 27 & $\begin{array}{l}28.1 .76 \\
7.2 .76 \\
10.3 .76 \\
14.4 .76 \\
9.6 .76 \\
24.9 .76\end{array}$ & $\begin{array}{l}++++ \\
++++ \\
- \\
-\end{array}$ & $\begin{array}{l}+3840 T L \\
+3000 T L \\
+650 T L \\
+150 T L \\
\text { Negative } \\
\text { Negative }\end{array}$ & $\begin{array}{l}+1 / 32 \\
+1 / 16 \\
+1 / 2 \\
\text { Doubtful } \\
\text { Negative } \\
\text { Negative }\end{array}$ & $\begin{array}{l}\text { Early latent infection } \\
\text { probably } 3 \text { or } 4 \text { months. } \\
\text { Treatment started } 27.1 .76 \text {. } \\
\text { Vibramycin } 100 \mathrm{mg} 8 \\
\text { hourly for } 14 \text { days }\end{array}$ \\
\hline 28 & $\begin{array}{l}6.2 .76 \\
13.2 .76 \\
26.3 .76 \\
3.5 .76 \\
13.10 .76\end{array}$ & $\begin{array}{l}++ \\
- \\
-\end{array}$ & $\begin{array}{l}+500 T \mathrm{~L} \\
+4288 \mathrm{TL} \\
+1110 \mathrm{TL} \\
\text { Negative } \\
\text { Negative }\end{array}$ & $\begin{array}{l}+1 / 32 \\
+1 / 64 \\
+1 / 8 \\
\text { Negative } \\
\text { Negative }\end{array}$ & $\begin{array}{l}\text { Secondary syphilis; date of } \\
\text { infection not known. } \\
\text { Treatment started } 11.2 .76 \text {. } \\
\text { Procaine penicillin } 1.0 \\
\text { megaunits daily for } 15 \text { days }\end{array}$ \\
\hline 29 & $\begin{array}{l}12.12 .75 \\
11.2 .75 \\
5.3 .76 \\
12.3 .76 \\
9.4 .76 \\
11.6 .76 \\
2.7 .76 \\
9.8 .76 \\
12.10 .76\end{array}$ & $\begin{array}{l}+ \\
+++ \\
+++ \\
- \\
- \\
- \\
-\end{array}$ & $\begin{array}{l}\text { Negative } \\
+2680 T L \\
+2304 T L \\
+1040 T L \\
+720 T L \\
+30 T L \\
+32 T L \\
\text { Negative } \\
\text { Negative }\end{array}$ & $\begin{array}{l}\text { Negative } \\
+1 / 16 \\
+1 / 16 \\
+1 / 8 \\
+1 / 4 \\
+ \text { neat } \\
\text { Doubtful } \\
\text { Negative } \\
\text { Negative }\end{array}$ & $\begin{array}{l}\text { Early latent syphilis, } \\
\text { probably infected } 14.11 .75 \text {. } \\
\text { Treatment started } 17.2 .76 \text {. } \\
\text { Procaine penicillin } 1.0 \\
\text { megaunits daily for } 15 \text { days }\end{array}$ \\
\hline
\end{tabular}

We wish to acknowledge the assistance of Dr Kay Hare who was responsible for all FTA-ABS tests, Dr C. B. S. Schofield for information on his patients, and Miss Kerr for her secretarial assistance.

\section{References}

Blum, G., Ellner, P. D., McCarthy, L. R., and Papachristos, T. (1973). Reliability of the treponemal haemagglutination test for the serodiagnosis of syphilis. Journal of Infectious Diseases, 127, 321-324.

Coffey, E. M., Bradford, L. L., Naritomi, L. S., and Wood, R. M. (1972). Evaluation of the qualitative and quantitative microhaemagglutination assay for antibodies to Treponema pallidum. Applied Microbiology, 24, 26-30.

Cox, P. M., Logan, L. C., and Stout, G. W. (1971). Further studies of a quantitative automated microhaemagglutination assay for antibodies to Treponema pallidum. The Public Health Laboratory, 29, 43-50.
Garner, M. F., Backhouse, J. L., Daskalopoulos, G., and Walsh J. L. (1972). Treponema pallidum haemagglutination test for syphilis: Comparison with the TPI and FTA-ABS tests. British Journal of Venereal Diseases, 48, 470-473.

Johnston, N. A. (1972). Treponema pallidum haemagglutination test for syphilis: Evaluation of a modified micro-method. British Journal of Venereal Diseases, 48, 474-478.

Le Clair, R. A. (1971). Evaluation of a qualitative haemagglutination test for antibodies to Treponema pallidum. Journal of Infectious. Diseases, 123, 668-670.

Macfarlane, D. E., Hare, K., and Elias-Jones, T. F. (1976). Evaluarion of automated large-scale screening tests for syphilis. Journal of Clinical Pathology, 29, 317-321.

O'Neill, P., Warner, R. W., and Nicol, C. S. (1973). Treponema pallidum haemagglutination assay in the routine serodiagnosis of treponemal disease. British Journal of Venereal Diseases, 49, 427-431.

Rathlev, G. (1965). Haemagglutination Test Utilising Antigens from Pathogenic and Apathogenic Treponema pallidum. VDT/RES/77.65. WHO: Geneva.

Sequeira, P. J. L., and Eldridge, A. E. (1973). Treponemal haemagglutination test. British Journal of Venereal Diseases, 49, 242-248.

Tomizawa, T., and Kasamatsu, S. (1966). Haemagglutination tests for diagnosis of syphilis. Japanese Journal of Medical Science and Biology, 19, 305-309. 